\title{
Karakteristik Histori Bencana Indonesia Periode 1815 - 2019 Berdasarkan Jumlah Bencana, Kematian, Keterpaparan dan Kerusakan Rumah Akibat Bencana
}

\author{
Jihan Fitriyani", Rio Khoirudin Apriyadi, Tri Winugroho, Dedy Hartono, I Dewa Ketut \\ Kerta Widana, Wilopo \\ Program Studi Manajemen Bencana, Fakultas Keamanan Nasional, Universitas Pertahanan, Indonesia \\ *Email: jihanfitriyani99@gmail.com
}

DOI: https://doi.org/10.33369/pendipa.5.3.322-327

\begin{abstract}
[Historical Characteristics of Disasters in Indonesia for the Period 1815 - 2019 Based on the Number of Disasters, Deaths, Exposure and Damage to Houses due to Disasters] Indonesia is a country with high potential for disasters in the world. Natural, non-natural and social disasters in Indonesia must be able to be used as laboratories and disaster experts as a form of state protection for its people. This paper aims to describe the historical characteristics of disasters based on indicators of the number of disaster events, deaths, exposure, and damage to houses due to disasters. The research was a descriptive quantitative using secondary sources in the form of the Indonesian Disaster Data and Information Management Database (DIBI), the Indonesian DisInvertar, data from books and journals related to the context of disaster histories. We found that the characteristics differed in each of the indicators studied. Meanwhile, the increasing graph is shown by each indicator in this study. Analysis of the historical characteristics of disasters is an important tool needed to support sustainable disaster management programs.
\end{abstract}

Keywords: Disaster Historical Characteristics; Number of Disasters; Dead; Exposure; House Damage.

\begin{abstract}
ABSTRAK
Indonesia merupakan negara dengan potensi bencana yang cukup tinggi di dunia. Bencana alam, non alam, dan sosial di Indonesia harus dapat dijadikan laboratorium dan tenaga ahli kebencanaan sebagai bentuk perlindungan negara kepada masyarakatnya. Artikel ini bertujuan untuk mendeskripsikan karakteristik histori bencana berdasarkan indikator jumlah kejadian bencana, kematian, keterpaparan, dan kerusakan rumah akibat bencana. Metode penelitian yang digunakan dalam penelitian ini adalah kuantitatif deskriptif dengan menggunakan data sekunder yang berupa Database Pengelolaan Data dan Informasi Bencana Indonesia (DIBI), DisInvertar Indonesia, data dari buku serta jurnal yang berkaitan dengan karakteristik histori bencana. Kami menemukan bahwa karakteristik yang berbeda-beda pada setiap indikator yang diteliti. Sementara itu, grafik meningkat ditunjukkan oleh setiap indikator dalam penelitian ini. Analisis karakteristik histori bencana merupakan alat penting yang diperlukan untuk mendukung program penanggulangan bencana yang berkelanjutan.
\end{abstract}

Kata kunci: Karakteristik Histori Bencana; Jumlah Bencana; Kematian; Keterpaparan; Kerusakan Rumah.

\section{PENDAHULUAN}

Histori kebencanaan di Indonesia mempunyai sejarah yang panjang mulai dari tahun 1815 hingga saat ini. Oleh karena itu sistem penanggulangan bencana di Indonesia telah berproses dari waktu ke waktu. (Yulianto et al., 2021).

Paradigma terhadap bencana telah mengalami banyak perubahan. Paradigma mitigasi bencana yang berkembang saat ini 
adalah proses panjang perubahan paradigma sebelumnya yang cenderung bersifat reaktif terhadap bencana. (Maarif, 2012).

Mitigasi bencana adalah serangkaian upaya untuk mengurangi risiko bencana. (RI, 2007). Risiko diartikan sebagai probabilitas dari bahaya atau ekspektasi dari kematian dan kerusakan properti akibat dari interaksi antara bencana dan kerentanan. (Aprilyanto, Apriyadi, Winugroho, Widana, \& Wilopo, 2021).

Penaksiran risiko dilakukan untuk menentukan sifat dan tingkat risiko dengan menganalisis potensi bahaya dan mengevaluasi kondisi kerentanan yang ada. (Agustin, Djauhari, \& Suryanita, 2020).

Sehingga secara umum risiko dapat diartikan sebagai potensi kerugian yang berupa kematian, luka, jiwa terancam, kerusakan atau kehilangan harta, dan gangguan kegiatan ekonomi atau kemasyarakatan yang ditimbulkan sebagai akibat dari bencana. (Djalante, Garschagen, Thomalla, \& Shaw, 2017)

Tujuan utama mitigasi bencana adalah pengurangan risiko bencana yang di alami oleh masyarakat. (Hartono et al., 2021). Upaya pengurangan risiko bencana dapat dilakukan dengan cara menghindari risiko, melawanan risiko, menghilangkan risiko, atau bahkan hidup berdampingan secara harmoni dengan risiko bencana. (Maarif \& Theresya, 2017).

Sebagai wujud implementasi UU 24/2007 atas pengurangan risiko bencana, Pemerintah, baik pusat maupun daerah, diharuskan membuat dan mengimplementasikan rencana penanggulangan bencana (RPB) sesuai dengan tugas dan kewenangannya. (RI, 2007). Dengan disusunnya RPB, semua kegiatan yang berkaitan dengan upaya penanggulangan bencana, dari pencegahan dan mitigasi, kesiapsiagaan, tanggap darurat hingga pemulihan, harus mengacu kepada dokumen ini. Penyusun dokumen ini tidak terlepas dari peran histori bencana yang terjadi di Indonesia. (Yulianto et al., 2021).

Beberapa penelitian telah dilakukan pada data histori bencana. (Pratomo, 2006) (Wahyuningtyas \& Pratomo, 2015) (Yulianto et al., 2021). Namun, kebanyakan dari studi ini hanya berkonsentrasi terhadap indikator jumlah kejadian bencana pada periode tertentu. Belum ada yang meninjau indikator histori bencana lainnya seperti jumlah kematian, keterpaparan, dan kerusakan rumah akibat bencana. Oleh karena itu, penelaahan terhadap karakteristik bencana berdasarkan indikator kematian, keterpaparan, dan kerusakan rumah akibat bencana sangat penting dilakukan sebagai informasi yang lebih baik kepada masyarakat dan pemangku kepentingan.

Makalah ini bertujuan untuk mengetahui karakteristik histori bencana Indonesia pada periode 1815 sampai dengan 2019 berdasarkan jumlah kejadian bencana, kematian, keterpaparan, dan kerusakan rumah akibat bencana. Analisis karakteristik histori bencana merupakan alat penting yang diperlukan untuk mendukung program penanggulangan bencana yang berkelanjutan, terlebih risiko multi bencana pada saat Covid-19. (Apriyadi \& Amelia, 2020).

\section{METODE PENELITIAN}

Sumber data dalam penelitian ini adalah sumber data sekunder. Data sekunder merupakan data yang diperoleh bukan dari observasi langsung, tetapi data diperoleh dari hasil penelitian yang telah dilakukan oleh peneliti sebelumnya, buku, jurnal, atau dokumen lain yang memuat topik yang berkaitan dengan penelitian. Penelitian ini menggunakan Database Pengelolaan Data dan Informasi Bencana Indonesia (DIBI) dan DisInvertar Indonesia (BNPB, 2021) pada periode 1815 sampai dengan 2019. Data ini digunakan untuk menggambarkan karakteristik histori bencana. Sumber data sekunder lainnya adalah buku dan jurnal yang berkaitan dengan histori bencana Indonesia pada periode 1815 sampai dengan 2019.

\section{HASIL DAN PEMBAHASAN}

\section{Karakteristik Histori Bencana Berdasarkan Jumlah Kejadian Bencana}

Berdasarkan persentase atas data kejadian bencana maka dapat diketahi bahwa jumlah kejadian bencana tertinggi adalah banjir sebanyak 10.438 kejadian (31\%), angin kencang 8098 kejadian (24\%), longsor 6050 kejadian (18\%), kebakaran sebanyak 2532 kejadian (7\%), kekeringan sebanyak 2124 kejadian (6\%), kebakaran hutan 1914 kejadian (5\%), gempa bumi 649 kejadian, jumlah bencana lainnya yang kurang dari 1\% sebanyak 1204 kejadian. (Gambar 1). 


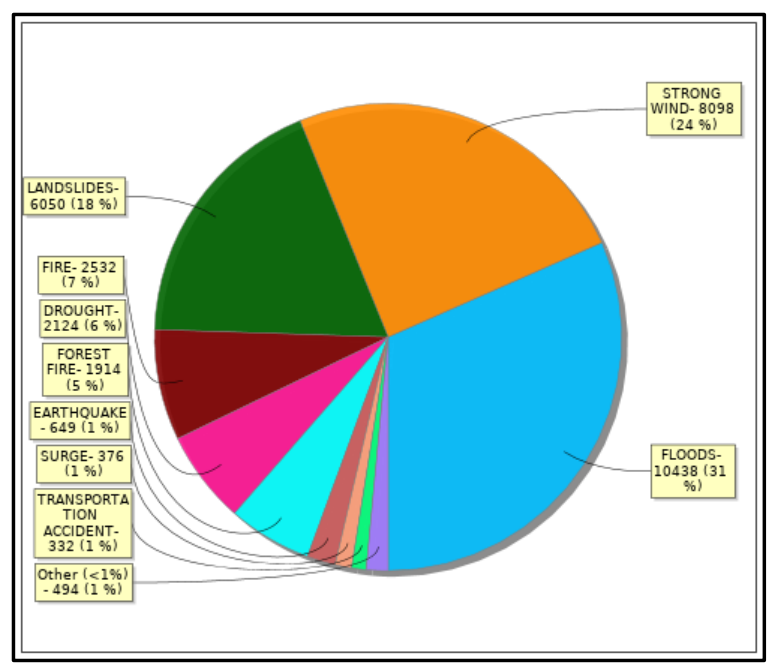

Gambar 1. Jumlah Kematian Akibat Bencana Berdasarkan Jenis Bencana.

Berdasarkan data DIBI pada periode 1815 sampai dengan 2019 dapat diketahui bahwa jumlah kejadian bencana tiap tahunnya di indonesia menunjukkan grafik yang meningkat dengan kejadian bencana tertinggi terjadi pada tahun 2019 sebanyak 3.885 bencana. (Gambar 2).

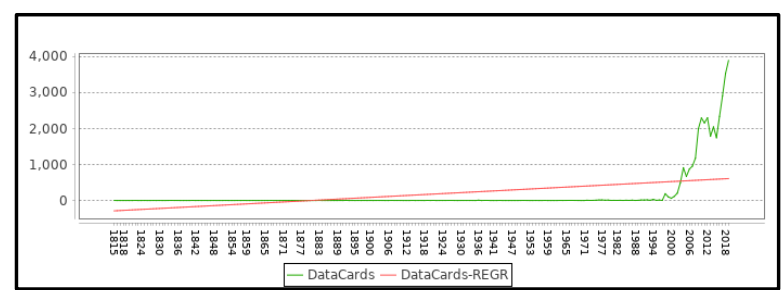

Gambar 2. Jumlah Kejadian Bencana Berdasarkan Periode Tahun.

Berdasarkan data DIBI pada periode 1815 sampai dengan 2019 jumlah kejadian bencana tertinggi terdapat di Provinsi Jawa Tengah dengan jumlah 7.113 bencana dan terendah pada Provinsi Papua Barat sebanyak 59 bencana. (Gambar 3).

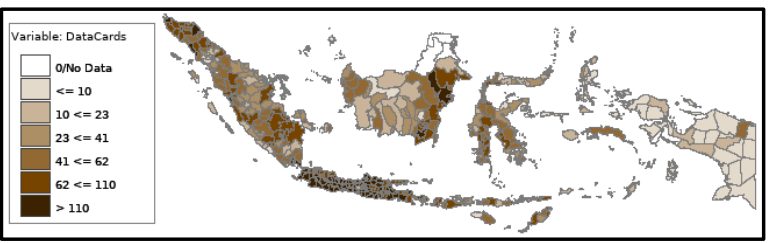

Gambar 3. Distribusi Spasial Jumlah Kematian Akibat Bencana Berdasarkan Provinsi.
Karakteristik Histori Bencana Berdasarkan Jumlah Kematian Akibat Bencana

Berdasarkan persentase atas data kematian akibat bencana maka dapat diketahi bahwa kematian tertinggi akibat bencana disebabkan oleh bencana gempa bumi dan tsunami jumlah kematian 132.999 (49\%), kematian akibat bencana gunung meletus sebanyak 78.634 jiwa (29\%), banjir 21.932 jiwa (8\%), gempa bumi 16.317 jiwa (6\%), konflik 6.059 jiwa (2\%), tsunami 5.064 jiwa (1\%), tanah longsor 2.888 jiwa (1\%), pejumlahan bencana lainnya yang berjumlah kurang dari $1 \%$ sebanyak 3.875 . (Gambar 4).

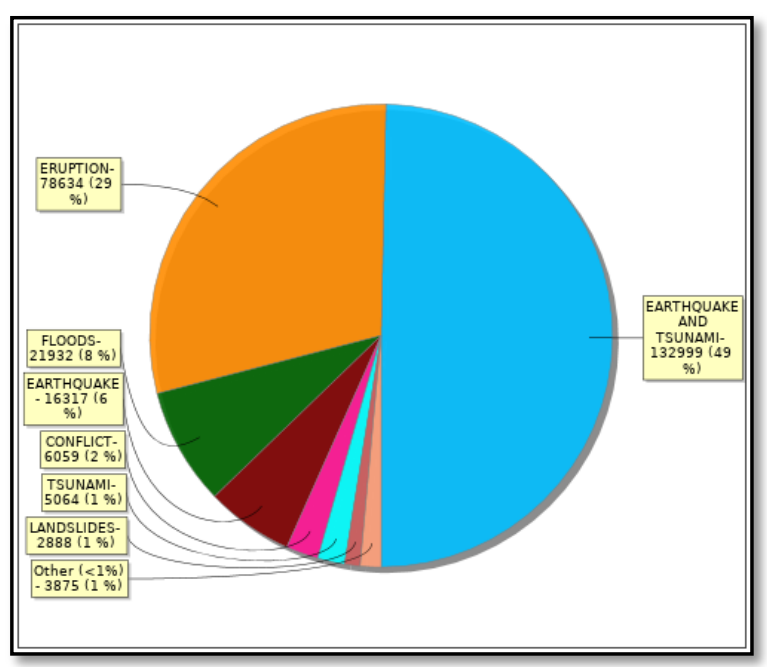

Gambar 4. Jumlah Kematian Akibat Bencana Berdasarkan Jenis Bencana.

Berdasarkan data DIBI pada periode 1815 sampai dengan 2019, dapat diketahui bahwa jumlah kematian akibat kejadian bencana tertinggi terjadi pada tahun 2004 dengan jumlah 130.768 jiwa. (Gambar 5).

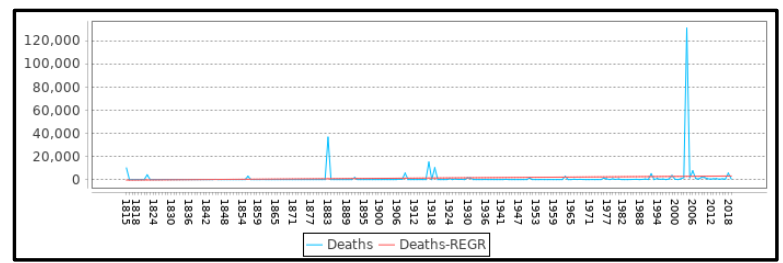

Gambar 5. Jumlah Kematian Akibat Bencana Berdasarkan Periode Tahun.

Berdasarkan data DIBI pada periode 1815 sampai dengan 2019 jumlah kematian akibat kejadian bencana tertinggi terdapat di Provinsi 
Nangroe Aceh Darussalam dengan jumlah kematian sebanyak 132.093 Jiwa dan terendah pada Provinsi Gorontalo sebanyak 41 jiwa. (Gambar 6).

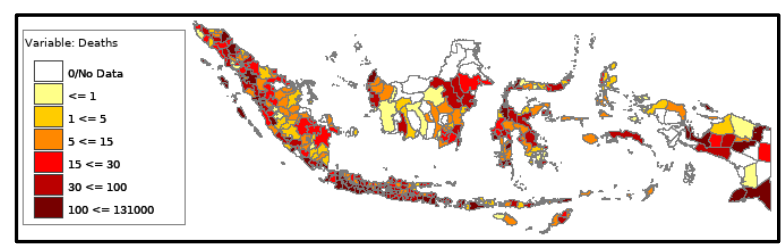

Gambar 6. Distribusi Spasial Jumlah Kematian Akibat Bencana Berdasarkan Provinsi.

Karakteristik Histori Bencana Berdasarkan Jumlah Keterpaparan Akibat Bencana (Terkena Langsung dan Terpengaruh Tidak Langsung).

Berdasarkan persentase atas angka keterpaparan bencana maka dapat diketahi bahwa jumlah keterpaparan tertinggi terjadi pada bencana banjir dengan 32.034.250 jiwa (56\%). (Gambar 7).

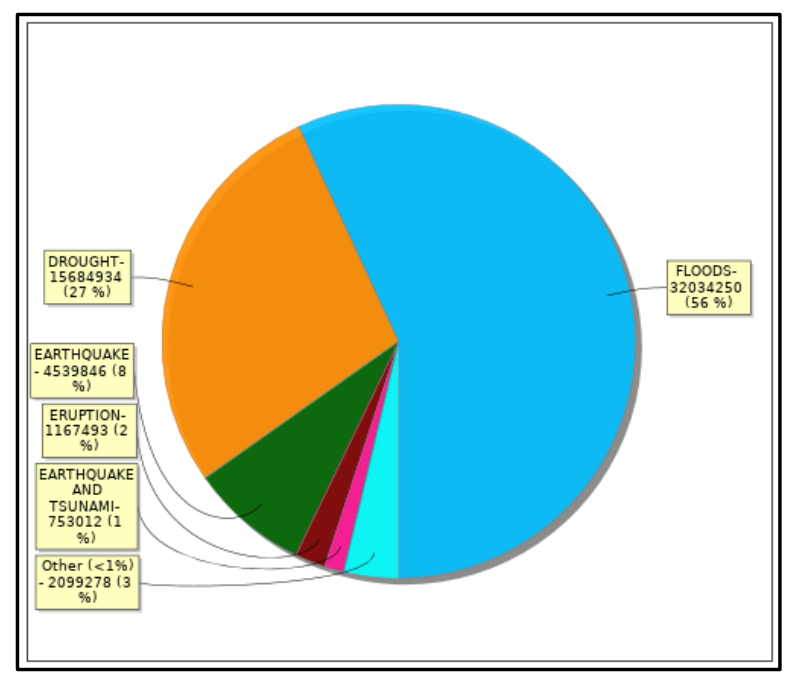

Gambar 7. Jumlah Keterpaparan Akibat Bencana Berdasarkan Jenis Bencana.

Berdasarkan data DIBI pada periode 1815 sampai dengan 2019 dapat diketahui bahwa keterpaparan akibat bencana tiap tahunnya di indonesia menunjukkan grafik yang meningkat dengan keterpaparan tertinggi terjadi pada tahun 2018 sebanyak 10.438.393 jiwa. (Gambar 8).

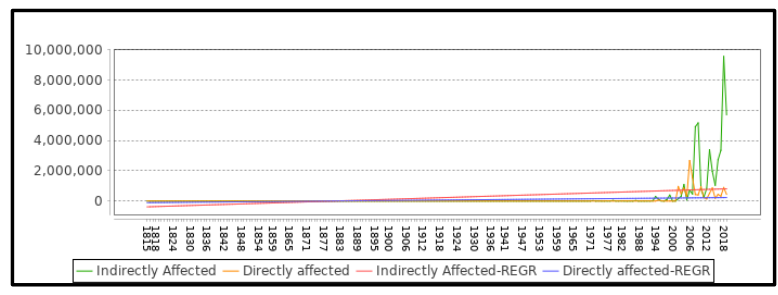

Gambar 8 Jumlah Kejadian Bencana Berdasarkan Periode Tahun .

Berdasarkan data DIBI pada periode 1815 sampai dengan 2019 jumlah kejadian bencana tertinggi terdapat di Provinsi Kalimantan Selatan dengan jumlah 10.129.762 jiwa dan terendah pada Provinsi Kepulauan RIAU sebanyak 3.883 jiwa. (Gambar 9).

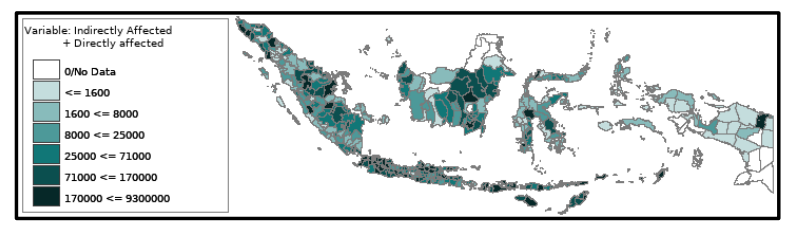

Gambar 9. Distribusi Spasial Keterpaparan Akibat Bencana Berdasarkan Provinsi.

\section{Karakteristik Histori Bencana Berdasarkan Jumlah Kerusakan Rumah Akibat Bencana.}

Berdasarkan persentase atas jumlah kerusakan rumah akibat bencana maka dapat diketahi bahwa jumlah kerusakan rumah akibat bencana tertinggi terjadi pada bencana gempa bumi dengan 623.901 bangunan (49\%). (Gambar 10).

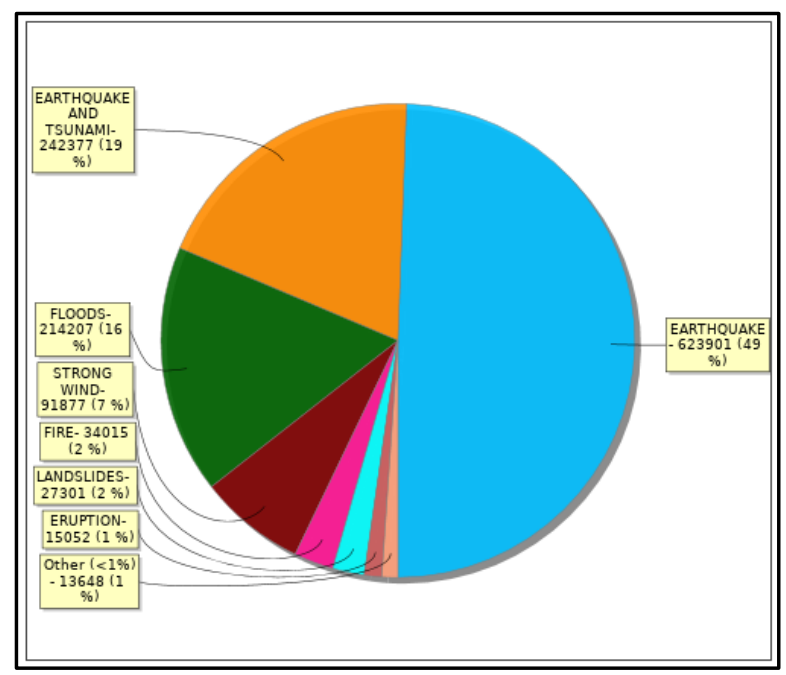

Gambar 10. Jumlah Kerusakan Rumah Akibat Bencana Berdasarkan Jenis Bencana. 
Berdasarkan data DIBI pada periode 1815 sampai dengan 2019 dapat diketahui bahwa jumlah rumah rusak akibat bencana tiap tahunnya di indonesia menunjukkan grafik yang meningkat dengan rumah rusak akibat bencana tertinggi terjadi pada tahun 2004 sebanyak 223.162 bangunan. (Gambar 11).

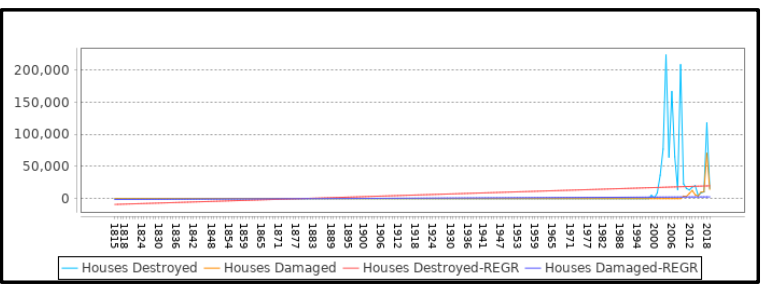

Gambar 11. Jumlah Kerusakan Rumah Akibat Bencana Berdasarkan Periode Tahun.

Berdasarkan data DIBI pada periode 1815 sampai dengan 2019 jumlah kerusakan rumah akibat bencana tertinggi terdapat di Provinsi Nangroe Aceh Darussalam dengan jumlah 235.566 bangunan dan terendah pada Provinsi Kalimantan Timur sebanyak 118 bangunan. (Gambar 12).

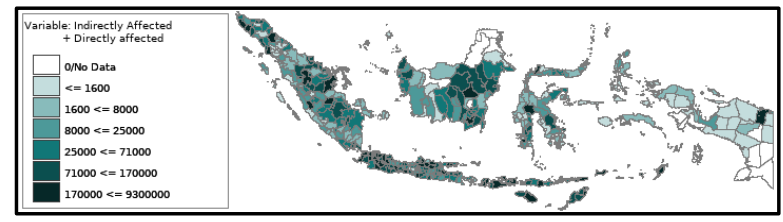

Gambar 12. Distribusi Spasial Kerusakan Rumah Akibat Bencana Berdasarkan Provinsi.

\section{KESIMPULAN}

Hasil kesimpulan dari penelitian ini menunjukkan karakteristik bahwa:

1. Berdasarkan jumlah kejadian bencana, banjir merupakan bencana dengan intensitas tertinggi dengan grafik yang meningkat intensitas kejadiannya setiap tahun. Jumlah bencana tertinggi atas data histori bencana Indonesia pada periode 1815 hingga 2019 terjadi pada tahun 2019 sebanyak 3.885 bencana. Sedangkan pada tingkat daerah, Provinsi Jawa Tengah merupakan penyumbang bencana tertinggi dengan jumlah 7.113 bencana dan yang terendah adalah Provinsi Papua Barat sebanyak 59 bencana.
2. Berdasarkan jumlah kematian akibat bencana, gempa bumi dan tsunami merupakan bencana dengan jumlah kematian tertinggi sebanyak 132.999 jiwa (49\%), dengan grafik yang meningkat jumlah kematiannya setiap tahun. Jumlah kematian akibat bencana tertinggi atas data histori bencana Indonesia pada periode 1815 hingga 2019 terjadi pada tahun 2004 sebanyak 130.768 jiwa. Sedangkan pada tingkat daerah, Provinsi Nangroe Aceh Darussalam merupakan penyumbang jumlah kematian akibat bencana tertinggi dengan jumlah 132.093 jiwa dan yang terendah adalah Provinsi Gorontalo sebanyak 41 jiwa.

3. Berdasarkan jumlah keterpaparan akibat bencana, banjir merupakan bencana dengan jumlah keterpaparan tertinggi sebanyak 32.034.250 jiwa (56\%), dengan grafik yang meningkat jumlah kematiannya setiap tahun. Jumlah keterpaparan akibat bencana tertinggi atas data histori bencana Indonesia pada periode 1815 hingga 2019 terjadi pada tahun 2018 sebanyak 10.438.393 jiwa. Sedangkan pada tingkat daerah, Provinsi Kalimantan Selatan merupakan penyumbang jumlah keterpaparan akibat bencana tertinggi dengan jumlah 10.129.762 jiwa dan yang terendah adalah Provinsi Kepulauan RIAU sebanyak 3.883 jiwa.

4. Berdasarkan jumlah kerusakan rumah akibat bencana, gempa bumi merupakan bencana dengan jumlah kerusakan rumah tertinggi sebanyak 623.901 bangunan (49\%), dengan grafik yang meningkat jumlah kematiannya setiap tahun. Jumlah keterpaparan akibat bencana tertinggi atas data histori bencana Indonesia pada periode 1815 hingga 2019 terjadi pada tahun 2004 sebanyak 223.162 jiwa. Sedangkan pada tingkat daerah, Provinsi Nangroe Aceh Darussalam merupakan penyumbang jumlah kerusakan rumah akibat bencana tertinggi dengan jumlah 235.566 bangunan dan yang terendah adalah Provinsi Kalimantan Timur sebanyak 118 bangunan.

Dari hasil penelitian ini, kami berharap para stakeholder dapat menjadikannya sebagai sumber informasi yang lebih baik dalam 
mendukung program penanggulangan bencana yang berkelanjutan,

\section{DAFTAR PUSTAKA}

Agustin, S., Djauhari, Z., \& Suryanita, R. (2020). Aplikasi Metode Rapid Visual Screening (RVS) Dalam Monitoring Kerentanan Bangunan Pemerintahan di Indragiri Hulu. Jurnal Rekayasa Sipil (JRS-Unand), 16(1), 38-48. doi:10.25077/jrs.16.1.38-48.2020

Aprilyanto, A., Apriyadi, R. K., Winugroho, T., Widana, I. D. K. K., \& Wilopo, W. (2021). Kesiapsiagaan Bencana Berbasis Komunitas Perkotaan. PENDIPA Journal of Science Education, 5(3), 284-291. doi:10.33369/pendipa.5.3.284-291

Apriyadi, R. K., \& Amelia, R. (2020). Tingkat Pengetahuan Kesiapsiagaan Resiko Bencana Tsunami disaat Pandemi Covid19. PENDIPA Journal of Science Education, 5(1), 56-62. doi:10.33369/pendipa.5.1.56-62

BNPB. (2021). DesInventar - Profile. Retrieved 13 January 2021, from https://dibi.bnpb.go.id/DesInventar/profilet ab.jsp? countrycode $=\mathrm{id} \&$ continue $=\mathrm{y}$

Djalante, R., Garschagen, M., Thomalla, F., \& Shaw, R. (2017). Disaster Risk Reduction in Indonesia. Disaster Risk Reduction in Indonesia: Progress, Challenges and Issues. Springer. Retrieved from http://link.springer.com/10.1007/978-3319-54466-3

Hartono, D., Apriyadi, R. K., Winugroho, T., Aprilyanto, A., Sumantri, S. H., Wilopo, W., \& Islami, H. S. (2021). Analisis Sejarah, Dampak, Dan Penanggulangan Bencana Gempa Bumi Pada Saat Pandemi Covid-19 Di Sulawesi Barat. PENDIPA Journal of Science Education, 5(2), 218224. doi:10.33369/pendipa.5.2.218-224
Maarif, S. (2012). Pikiran dan Gagasan Penanggulangan Bencana di Indonesia. Jakarta: Badan Nasional Penanggulangan Bencana.

Maarif, S., \& Theresya, J. (2017). Bunga Rampai Penelitian Kebencanaan (Program Studi Manajemen Bencana 2016-2018). Bogor: PT. Idemedia Pustaka Utama.

Pratomo, I. (2006). Klasifikasi gunung api aktif Indonesia, studi kasus dari beberapa letusan gunung api dalam sejarah. Indonesian Journal on Geoscience, 1(4), 209-227. doi:10.17014/ijog.vol1 no4.20065

RI. (2007). Undang-Undang No. 24 Tahun 2007 Tentang Penanggulangan Bencana. Jakarta: Pemerintah Republik Indonesia.

Wahyuningtyas, A., \& Pratomo, R. A. (2015). Identifikasi Potensi Multi-Bencana Di Kabupaten Landak Kalimantan Barat. Geoplanning: Journal of Geomatics and Planning, 2(1), 10-21. doi:10.14710/geoplanning.2.1.10-21

Yulianto, S., Apriyadi, R. K., Aprilyanto, A., Winugroho, T., Ponangsera, I. S., \& Wilopo, W. (2021). Histori Bencana dan Penanggulangannya di Indonesia Ditinjau Dari Perspektif Keamanan Nasional. PENDIPA Journal of Science Education, 5(2), 180-187.

doi:10.33369/pendipa.5.2.180-187 